\title{
Long-term effect of ethanol on the bond strength of fiber-glass posts to root dentin
}

\author{
Dimorvan Bordin ${ }^{\mathrm{a}}$, Yuri Wanderley Cavalcanti ${ }^{\mathrm{a}}$, Ana Paula Farina ${ }^{\mathrm{b}}$, Bruno Carlini-Júnior $^{\mathrm{b}}$, Doglas Cecchin $^{\mathrm{b}}$
}

\begin{abstract}
Objective: To evaluate the long-term effect of ethanol $(\mathrm{EtOH})$ application on the bond strength of adhesive systems used in post luting to root dentin.

Methods: Bovine roots $(n=40)$ had their root channel prepared for post luting and were etched with $37 \%$ phosphoric acid (15s). Specimens were distributed according to adhesive system and $\mathrm{EtOH}$ application. Control groups received only the application of adhesives Adper ScothBond Multi-Purpose Plus (ASb), ou Adper Single Bond (SB). Experimental groups received previous EtOH application for 1 minute ( $\mathrm{EtOH}+\mathrm{ASb}$ and $\mathrm{EtOH}+\mathrm{SB}$ groups). After fiber-glass post luting, specimens were stored for $24 \mathrm{~h}$, or 12 months, and later subjected to push-out test $(\mathrm{n}=5)$. Data were analyzed by three-way analysis of variance and Tukey test $(\alpha<0.05)$.

Results: The $\mathrm{EtOH}$ application did not influence the bond strength values in immediate evaluation $(24 \mathrm{~h})$, regardless of the adhesive system used ( $p>0.05)$. After 12 months, it was observed significant statistically reduction of adhesive resistance $(p<0.05)$; however the $\mathrm{EtOH}+\mathrm{SB}$ group did not presented statistical difference between the evaluated storage periods ( $p>0.05)$.

Conclusion: $\mathrm{EtOH}$ pre-treatment contributes to maintain the long-term bond strength, when water and ethanol-based adhesive system is used.
\end{abstract}

Keywords: Cementation; intracanal retention; root posts; ethanol

\section{Efeito em longo prazo da aplicação de etanol na resistência adesiva de pinos de fibra de vidro cimentados à dentina radicular}

\section{Resumo}

Objetivo: Avaliar o efeito em longo prazo da aplicação de etanol $(\mathrm{E} t \mathrm{OH})$ na resistência adesiva de sistemas adesivos utilizados na cimentação de pinos à dentina radicular.

Métodos: Raízes bovinas $(n=40)$ tiveram o canal radicular preparado para receber pino, sendo realizado o condicionamento com ácido fosfórico 37\% (15s). Os espécimes foram distribuídos de acordo o sistema adesivo e aplicação de EtOH. Grupos controles receberam apenas aplicação dos adesivos Adper ScothBond Multi-Purpose Plus (ASb), ou Adper Single Bond (SB). Grupos experimentais receberam aplicação prévia de $\mathrm{EtOH}$ durante 1 minuto (EtOH+ASb e EtOH+SB). Após a cimentação, os espécimes, foram armazenados por $24 \mathrm{~h}$, ou 12 meses, sendo submetidos ao teste push out $(n=5)$. Os dados foram avaliados estatisticamente por análise de variância a 3 critérios e teste Tukey $(\alpha<0,05)$.

Resultados: $\mathrm{O}$ tratamento com $\mathrm{E} t \mathrm{OH}$ não influenciou os valores de resistência de união na avaliação imediata $(24 \mathrm{~h})$, independente do sistema adesivo empregado $(p>0,05)$. Após 12 meses, observou-se redução estatisticamente significante da resistência adesiva $(p<0,05)$, entretanto o grupo $\mathrm{EtOH}+\mathrm{SB}$ não mostrou diferença estatística entre os tempos avaliados $(p>0,05)$.

Conclusão: $\mathrm{O}$ pré-tratamento com EtOH contribui para manutenção da resistência de união em longo prazo, quando utilizado sistema adesivo a base de água e etanol.

Palavras-chave: Cimentação; técnica para retentor intra-radicular; pinos dentários; etanol a Department of Periodontology and Prosthodontics, Piracicaba Dental School, University of Campinas (UNICAMP), Piracicaba, Sao Paulo, Brazil.

${ }^{b}$ Department of Restorative Dentistry, University of Passo Fundo (UPF) Dental School, Passo Fundo, Rio Grande do Sul, Brazil. 


\section{Introduction}

Fiber-glass posts have been used to restore teeth with significant loss of coronal structure, as an alternative to metal cast posts. Besides the esthetic advantages related with its light transmission characteristics and similar color to teeth structures, the fiber-glass posts may be adhesively cemented and have a modulus of elasticity close to that of dentin, which minimizes the possibility of fracture of the remaining root [1]. However, the adhesive bonding of such posts to root dentin remains a frequently observed problem, due to hydrolytic degradation of the hybrid layer, which can result to the long-term reduction in bond strength [2-4].

Therefore, the adhesive failure within the hybrid layer can be the result of incomplete replacement of water prior to adhesive application [5-8]. Current adhesive systems use solvents such as water, acetone, alcohol or a combination of those components in order to remove the excess of moisture within the demineralized dentinal matrix, thus optimizing the long-term stability of the hybrid layer $[9,10]$. By contrast, the inclusion of a higher volume of solvent in the adhesive system results in a weakened hybrid layer $[8,11]$.

Pretreatment of the dentin with ethanol (EtOH), following acid etching and prior to the application of the adhesive, has been used to remove the excess of residual water from the etched dentin, thus optimizing the stability of hybrid layer, due to higher infiltration of the adhesive, as well as maintaining the bond strength values through time $[9,10,12]$.

Studies have evaluated the effect of pretreating root dentin with EtOH on the bond strength of different adhesive systems, which revealed bond strength values that were maintained initially $[8,13]$. However, such studies have tested self-etching adhesive systems or self-etching resin cements only for a short period of time [8,13-15]. Consequently, long-term evaluation is necessary, including single or twobottles systems, which contain different formulations of solvents in their composition (water or a mixture of water and alcohol), when used after acid etching in combination with conventional resin cements.

Considering the diversity of adhesive systems available in the market, the aim of the present study was to evaluate the long-term effect of ethanol (EtOH) application on the bond strength of adhesive systems used in post luting to root dentin, Tested hypothesis was that the bond strength is influenced through time by pre-treatment with $\mathrm{EtOH}$, and by the adhesive system used.

\section{Methods}

\section{Experimental design}

This was a blind in vitro study, randomized in relation to the analyses, where the study factors were: the application of ethanol (EtOH), the adhesive system used and the long-term bond strength. Forty bovine roots were prepared and etched using $37 \%$ phosphoric acid for 15 seconds and subsequently divided according to treatments: no treatment (control) application of the adhesive system Adper Scotchbond MultiPurpose $^{\circledR}$ (ASb); no treatment (control) - application of the adhesive system Single Bond ${ }^{\circledR}$ (SB); irrigation with $100 \%$ ethanol for 1 minute, followed by the application of Adper Scotchbond Multi-Purpose ${ }^{\circledR}$ (EtOH+ASb); irrigation with $100 \%$ ethanol for 1 minute, followed by the application Single Bond ${ }^{\circledR}(\mathrm{EtOH}+\mathrm{SB})$.

\section{Specimen preparation}

Forty bovine incisors of similar root anatomy and fully developed root apices were selected, stored in $0,02 \%$ Thymol solution and prepared one month after extraction. The crown of every tooth was removed at the cementoenamel junction at a right angle with the longitudinal axis of the root using a diamond disk at low speed and water-cooling (Isomet 2000; Buehler Ltd., Lake Bluff, IL, USA). Subsequently, apical sealing was performed using temporary restoration material $\left(\mathrm{Cavit}^{\mathbb{R}} \mathrm{W}\right.$, Premier Dental Products, Rio de Janeiro, RJ, Brazil).

All root canals were prepared by an appropriately trained operator. The root pulp and the pre-dentin were removed from the canal, which was then prepared using a rotatory bur Largo \#6 and a K-type file \#130 (Maillefer ${ }^{\circledR}$, Ballaigues, VD, Switzerland). The root canals were irrigated using $5 \mathrm{~mL}$ of saline solution $(0.85 \% \mathrm{NaCl})$ to remove the remaining tissue. The canals were etched using $37 \%$ phosphoric acid (Cond AC $37^{\circledR}$, FGM, Joinville, SC, Brazil) for 15 seconds, rinsed with $20 \mathrm{~mL}$ of saline solution, and randomly divided by lottery into 4 groups, according to the treatments and adhesive systems used.

For the control groups, the adhesive systems were applied without the previous EtOH treatment. Control groups were named as Adper Scotchbond Multi-Purpose ${ }^{\circledR}-\mathrm{ASb}(3 \mathrm{M}$ ESPE, St. Paul, MN, EUA); and Adper Single Bond - SB (3M ESPE, St. Paul, MN, EUA). The composition and classification of adhesive systems used in this study are presented in Table 1.

Table 1. Composition and classification of adhesive systems used in this study.

\begin{tabular}{l|l|l}
\hline \multicolumn{1}{c}{ Adhesive System } & \multicolumn{1}{c}{$\begin{array}{c}\text { Adhesive System } \\
\text { classification }\end{array}$} & \multicolumn{1}{c}{$\begin{array}{c}\text { Adhesive } \\
\text { Solvent }\end{array}$} \\
$\begin{array}{l}\text { Adper Scotchbond Multi-Purpose }{ }^{\circledR} \\
\text { (3M ESPE, St. Paul, MN, EUA) }\end{array}$ & $\begin{array}{l}\text { Conventional three-steps } \\
\text { adhesive. Two bottles. }\end{array}$ & Water \\
$\begin{array}{l}\text { Single Bond } \\
\text { (3M ESPE, St. Paul, MN, EUA) }\end{array}$ & $\begin{array}{l}\text { Conventional two-steps } \\
\text { adhesive. One bottle }\end{array}$ & $\begin{array}{l}\text { Water and } \\
\text { Ethanol }\end{array}$ \\
\hline
\end{tabular}

For ASb group, two applications of primer were performed for 15 seconds, within 1 minute interval between them, for solvent evaporation. After this, an layer of adhesive was applied, followed by removing the excess with the aid of sterile absorbent paper cones (Tanari ${ }^{\circledR}$, Manaus, AM, Brazil) and light curing for 30 seconds (Ultraled ${ }^{\circledR}$, Dabi Atlante, Ribeirão Preto, SP, Brazil). The SB group received two applications of adhesive system, within 
1 minute interval between them, for solvent evaporation. After removing the excess with the aid of sterile absorbent paper cones, light curing was performed for 30 seconds. Experimental groups had the roots rinsed with $\mathrm{EtOH}$, for 1 munite, previously the adhesive system application. The adhesive system application followed the same protocol described before, and groups were named as $\mathrm{EtOH}+\mathrm{ASb}$ and $\mathrm{EtOH}+\mathrm{SB}$.

The fiber-glass posts were cleaned with $37 \%$ phosphoric acid for 30 seconds, rinsed with saline $(0.85 \% \mathrm{NaCl})$, and dried using jets of air. Two layers of bonding agent Silane (Silano $^{\circledR}$, Angelus ${ }^{\circledR}$, Londrina, PR, Brasil) were applied onto the posts (2 minutes apart), followed by a layer of the adhesive (Scotchbond Multi-Porpose ${ }^{\circledR}$ ), which was light-cured (Ultraled ${ }^{\circledR}$, Dabi Atlante, Ribeirão Preto, SP, Brasil) from each aspect for 30 seconds, i.e. 2 minutes altogether [13].

The dual-cure resin cement $\left(\mathrm{AllCem}{ }^{\circledR}\right.$ dual-cure A1, $\mathrm{FGM}^{\circledR}$, Joinville, SC, Brazil) was mixed and inserted into the canal using a spiral bur. Subsequently, the fiber-glass post (White Post DC ${ }^{\circledR}$, size 4, FGM ${ }^{\circledR}$, Joinville, SC, Brasil) was coated in resin cement and placed into the canal under finger pressure for 20 seconds. The excess of material was removed and the cement light-cured for 2 minutes.

The specimens from each group were randomly divided by lottery into two subgroups $(\mathrm{n}=5)$, according to storage time: $24 \mathrm{~h}$ (immediate group) and 12 months in sterile distilled and deionized water (long-term group). The number of specimens in each group was determined by preliminary tests, which demonstrated that the sample sized was enough to yield an adequate power ( $80 \%)$ to detect statistically significant differences.

\section{Push-out test}

Each root was cross-sectioned perpendicular to the long axis using a water-cooled diamond disk at low speed (Isomet 2000, Buehler Ltd.), yielding six slices of approximately $1 \mathrm{~mm}$ in thickness. The first slice was excluded, thus leaving 5 slices for testing. The mean bond strength was calculated per root canal $(\mathrm{n}=5)$.

The push-out test was performed via the application of a load in the apex-crown direction at a speed of $0.5 \mathrm{~mm} / \mathrm{min}$, until the fiber-glass post was dislodged.
Bond strength values were recorded in Newton $(\mathrm{N})$ and converted into MPa by dividing the reading in $\mathrm{N}$ by the interface area $\left(\mathrm{mm}^{2}\right)$ between the post and the dentin. The latter was calculated using the formula $\pi(\mathrm{R}+\mathrm{r})$ $[(\mathrm{h} 2+(\mathrm{R}-\mathrm{r}) 2] 0.5$, where $\mathrm{R}$ is the radius of the coronal aspect of the root, $r$ is the radius of the apical aspect of the root and $h$ is the thickness of the slice [13). The thickness of each slice was measured using a digital gauge (Vonder, Curitiba, PR, Brazil) and the bonding area of each root segment was measured at $20 \times$ magnification, using a stereoscopic lens (Lambda Let 2, ATTO Instruments Co., Hong Kong, China) and the software ImageLab 2.3 (University of São Paulo, São Paulo, SP, Brazil).

\section{Statistical analyses}

The mean bond strength values were statistically tested using three-way Analysis of Variance and Tukey's comparison tests $(\alpha<0.05)$. The factors under study were: the application of ethanol (EtOH), the adhesive system used and the long-term bond strength.

\section{Results}

Table 2 presents the bond strength values of fiber-glass posts according to root dentin treatment, adhesive system and storage time. EtOH treatment did not have an effect on the immediate bond strength values $(24 \mathrm{~h})$, regardless of the adhesive system used ( $p>0.05$ ). After 12 months, a statistically significant reduction in bond strength was observed $(\mathrm{p}<0.05)$, except for the $\mathrm{EtOH}+\mathrm{SB}$ group, which did not show a significant difference between the two conditions evaluated $(p>0,05)$. Table 2 shows the bond strength values of fiber-glass posts according to the root dentin treatment, the adhesive system and the storage times evaluated.

There was a statistically significant interaction $(p<0.05)$ for the combined effect of the three factors under study. It was observed that pre-treatment with $\mathrm{EtOH}$, associated with the use of an adhesive system with water and ethanolbased solvent, contributed to maintaining the integrity of union after 12 months of storage. A statistically significant difference $(\mathrm{p}<0.05)$ between storage periods was observed for all the other groups.

Table 2. Bond strength of fiber-glass posts according to root dentin treatment, adhesive system and storage time.

\begin{tabular}{|c|c|c|c|}
\hline \multirow{2}{*}{ Pretreatment } & \multirow{2}{*}{ Adhesive System } & \multicolumn{2}{|c|}{ Storage time } \\
\hline & & Immediate & 12 months \\
\hline \multirow[t]{2}{*}{ No treatment (control) } & Adper Scotchbond Multi-Purpose ${ }^{\circledR}$ & $9.16 \pm 3.87^{\mathrm{Aa}^{*}}$ & $4.49 \pm 1.99^{A b^{*}}$ \\
\hline & Single Bond ${ }^{\circledR}$ & $9.26 \pm 4.08^{\mathrm{Aa}^{*}}$ & $4.66 \pm 2.03^{A b^{*}}$ \\
\hline \multirow[t]{2}{*}{ Ethanol } & Adper Scotchbond Multi-Purpose ${ }^{\circledR}$ & $8.61 \pm 3.00^{\mathrm{Aa}^{\star}}$ & $5.84 \pm 2.71^{\mathrm{Ab}^{*}}$ \\
\hline & Single Bond ${ }^{\circledR}$ & $9.31 \pm 2.80 \mathrm{Aa}^{*}$ & $9.46 \pm 3.26^{\mathrm{Ba}+}$ \\
\hline
\end{tabular}

Different capital letters indicate significant difference between pretreatments $(p<0.05)$

Different lower case letters indicate significant difference between storage times $(p<0.05)$

Different symbols indicate significant difference between adhesive systems $(p<0.05)$ 


\section{Discussion}

The tested hypothesis in this study was partially rejected, once the results have demonstrated that the preservation of the bond strength by EtOH was obtained only for the group in which a two-steps adhesive system $(\mathrm{EtOH}+\mathrm{SB})$ was used, due probably to the solvent incorporated into the adhesive system (water and ethanol). The EtOH present in the SB system, when combined with the EtOH applied onto the root dentin, may have removed the excess of water from the etched dentin, creating a stable long-term bond [15].

In the specimens with no Et-OH pre-treatment (control), for which a water and ethanol-based adhesive was used (SB), the adhesive solvent in its composition was not able to effectively remove the excess of moisture, resulting in similar bond strength values to the groups for which the adhesive containing water-based solvents was used (ASb and $\mathrm{EtOH}+\mathrm{ASb}$ ). Therefore, the maintenance of the bond strength values was influenced by the use of $\mathrm{EtOH}$ as a pretreatment combined with a water and ethanol-based adhesive system (SB). These findings corroborate those in the literature, which suggest that the remaining moisture in the matrix contributes towards the hydrolytic degradation of the adhesive interface and the lixiviation of resin components $[2,3]$.

The use of adhesive systems that contain water as a solvent resulted in a long-term reduction in bond strength values, as per observed in this study, corroborating the data in the literature [10]. In the groups treated with Adper ScotchBond Multi-Purpose ${ }^{\circledR}$, the expected evaporation of excess water by EtOH pretreatment may have been inhibited by the presence of water in the composition of the adhesive system, which may have accounted for the reduced values after 12 months.

Another relevant aspect to EtOH pretreatment is the lesser diameter of the collagen fibers when compared with the dentin matrix saturated with water. When the dentin is saturated with ethanol, horizontal shortening of the fibers occurs by approximately $83 \%$, resulting in greater space between the fibrils. This shortening happens due to hydrogen bridges formed within each fibril and the greater interfibrillar space becomes available for resin impregnation $[8,16]$. Therefore, a greater interfribillar space may explain the higher bond strength [15].

Similar to the findings from this study, the effectiveness of the immediate bond by adhesive systems may be considered satisfactory and not influenced by EtOH pretreatment [12,17]. Nonetheless, the maintenance of long-term bond strength values (after 12 months) was observed only when EtOH pretreatment was used with an adhesive system containing water and ethanol as solvents $(\mathrm{EtOH}+\mathrm{SB})$, which corroborate the findings in the literature $[3,12,13,16,18]$.

The use of simplified adhesive systems, such as the SB, can inhibit the complete polymerization of resin cements with chemical or dual activation, due to acid-base reaction of acidic monomers with amines used as polymerization initiators [20-22]. However, the incomplete polymerization does not occur in all the layer of the resin cement, but in some isolated spots in the surface layer [21], which may reduce the bond strength, but without derail their use [20]. The incompatibility of these materials, however, seems not to have been observed in this study, where the use of $\mathrm{EtOH}$ pre-treatment and the SB adhesive system contributed to greater long-term bond strength.

In the present study, bovine teeth were used for performing bond strength tests because the bovine dentin has been increasingly used as a substitute for human dentin, due to its availability and easily sample standardization $[23,24]$. In addition, the bovine dentin morphological features, such as number of dentinal tubules and organic matrix, are similar to those found in human dentin $[23,25]$.

The analysis of bond strength durability in this study was limited to 12 months, following storage in sterile distilled and deionized water. The evaluation of bond strength and durability using other adhesive systems, following ageing assays and thermocycling, may contribute to ameliorate the knowledge on the effects of dentinal pretreatment with EtOH on the bond strength to root dentin. With the advance of new restorative materials and adhesive protocols, further studies are needed to evaluate materials and techniques, as well as the durability of adhesive procedures and their clinical behavior.

\section{Conclusion}

It was concluded that the ethanol application, prior to the use of an adhesive system which solvent is a mixture of water and ethanol, helps to maintain the long-term bond strength of fiber-glass posts cemented to the root dentine.

\section{References}

1. Al-Omiri MK, Mahmoud AA, Rayyan MR, Abu-Hammad O. Fracture resistance of teeth restored with post-retained restorations: an overview. Journal of endodontics 2010;36:1439-49.

2. Vaidyanathan TK, Vaidyanathan J. Recent advances in the theory and mechanism of adhesive resin bonding to dentin: a critical review. Journal of biomedical materials research Part B, Applied biomaterials 2009; 88:558-78

3. Malacarne J, Carvalho RM, de Goes MF, Svizero N, Pashley DH, Tay FR, et al. Water sorption/solubility of dental adhesive resins. Dent Mater 2006; 22:973-80

4. Hashimoto $M$, Ohno $H$, Sano $H$, Kaga M, Oguchi $H$. In vitro degradation of resin-dentin bonds analyzed by microtensile bond test, scanning and transmission electron microscopy. Biomaterials 2003;24:3795-803.

5. Ito S, Hashimoto M, Wadgaonkar B, Svizero N, Carvalho RM, Yiu C, et al Effects of resin hydrophilicity on water sorption and changes in modulus of elasticity. Biomaterials 2005;26:6449-59.

6. Toroian D, Lim JE, Price PA. The size exclusion characteristics of type collagen: implications for the role of noncollagenous bone constituents in mineralization. The Journal of biological chemistry 2007;282:22437-47.

7. Perdigao J, Frankenberger R, Rosa BT, Breschi L. New trends in dentin/ enamel adhesion. American journal of dentistry 2000;13:25D-30D.

8. Carvalho CA, Cantoro A, Mazzoni A, Goracci C, Breschi L, Ferrari M. Effect of ethanol application on post-luting to intraradicular dentine. International endodontic journal 2009;42:129-35

9. Pashley DH, Tay FR, Carvalho RM, Rueggeberg FA, Agee KA, Carrilho M et al. From dry bonding to water-wet bonding to ethanol-wet bonding. A review of the interactions between dentin matrix and solvated resins using a macromodel of the hybrid layer. Am J Dent 2007;20:7-20.

10. Sadek FTP, D.H. Nishitan,i Y. Carrilho, M.R. Donnelly, A. Ferrari, M. Tay, F.R. application of hydrophobic resin adhesives to acid-etched dentin with an alternative wet bonding technique. J Biomed Mater Res A 2008; 84:19-29. 
11. Van Landuyt KL, De Munck J, Snauwaert J, Coutinho E, Poitevin A Yoshida Y, et al. Monomer-solvent phase separation in one-step self-etch adhesives. Journal of dental research 2005;84:183-8.

12. Tay FR, Gwinnett AJ, Pang KM, Wei SH. Resin permeation into acidconditioned, moist, and dry dentin: a paradigm using water-free adhesive primers. Journal of dental research 1996;75:1034-44.

13. Cecchin D, de Almeida JF, Gomes BP, Zaia AA, Ferraz CC. Effect of chlorhexidine and ethanol on the durability of the adhesion of the fiber post relined with resin composite to the root canal. Journal of endodontics 2011;37:678-83

14. Cecchin D, de Almeida JF, Gomes BP, Zaia AA, Ferraz CC. Influence of chlorhexidine and ethanol on the bond strength and durability of the adhesion of the fiber posts to root dentin using a total etching adhesive system. Journal of endodontics 2011;37:1310-5

15. Faria ESAL, Mendonca AA, Garcez RM, Oliveira Ada S, Moreira AG, Moraes RR. Adhesion strategy and early bond strengths of glass-fiber posts luted into root canals. Brazilian oral research 2012;26:485-7.

16. Carvalho RM, Mendonca JS, Santiago SL, Silveira RR, Garcia FC, Tay FR, et al. Effects of HEMA/solvent combinations on bond strength to dentin. Journal of dental research 2003;82:597-601.

17. Tay FR, Pashley DH, Kapur RR, Carrilho MR, Hur YB, Garrett LV, et al Bonding BisGMA to dentin--a proof of concept for hydrophobic dentin bonding. Journal of dental research 2007;86:1034-9.

18. De Munck J, Van Landuyt K, Peumans M, Poitevin A, Lambrechts P, Braem $M$, et al. A critical review of the durability of adhesion to tooth tissue: methods and results. Journal of dental research 2005;84:118-32.
19. Armstrong SR, Vargas MA, Chung I, Pashley DH, Campbell JA, Laffoon JE et al. Resin-dentin interfacial ultrastructure and microtensile dentin bond strength after five-year water storage. Operative dentistry 2004;29:705-12.

20. Franco EB, Lopes LG, D'Alpino PH, Pereira JC. Influence of $\mathrm{pH}$ of different adhesive systems on the polymerization of a chemically cured composite resin. Brazilian dental journal 2005;16:107-11.

21. Salz U, Zimmermann J, Salzer T. Self-curing, self-etching adhesive cement systems. The journal of adhesive dentistry 2005;7:7-17.

22. Jayasooriya PR, Pereira PN, Nikaido T, Tagami J. Efficacy of a resin coating on bond strengths of resin cement to dentin. Journal of esthetic and restorative dentistry: official publication of the American Academy of Esthetic Dentistry [et al.] 2003:15:105-13; discussion 13

23. Reis A, Loguercio AD, Carvalho RM, Grande RH. Durability of resin dentin interfaces: effects of surface moisture and adhesive solvent component. Dental materials : official publication of the Academy of Dental Materials 2004;20:669-76

24. Schmalz G, Hiller KA, Nunez LJ, Stoll J, Weis K. Permeability characteristics of bovine and human dentin under different pretreatment conditions. Journal of endodontics 2001;27:23-30.

25. Schilke R, Lisson JA, Bauss O, Geurtsen W. Comparison of the number and diameter of dentinal tubules in human and bovine dentine by scanning electron microscopic investigation. Archives of oral biology 2000;45: 355-61. 